\title{
Origin of Transient and Sustained Responses in Ganglion Cells of the Retina
}

\author{
Gautam B. Awatramani and Malcolm M. Slaughter \\ Departments of Physiology and Biophysics and Ophthalmology, State University of New York at Buffalo, Buffalo, \\ New York 14214
}

\begin{abstract}
Phasic and tonic light responses provide a fundamental division of visual information that is thought to originate in the inner retina. However, evidence presented here indicates that this duality originates in the outer retina. In response to a steady light stimulus, the temporal responses of On-bipolar cells fell into two groups. In one group, the light response peaked and then rapidly declined $(\tau \sim 400 \mathrm{msec})$ close to the resting membrane potential. At light offset, these cells exhibited a transient afterhyperpolarization. In the second group of On-bipolar cells, the light response declined 10-fold more slowly and reached a steady depolarization that was $\sim 40 \%$ of the peak response. These neurons had a slowly decaying afterhyperpolarization at light offset. A metabotropic glutamate antagonist, (RS)- $\alpha$-cyclopropyl4-phosphonophenylyglycine (CPPG), blocked light responses in both types of On-bipolar cell. CPPG only slightly depolarized
\end{abstract}

In the vertebrate retina, photoreceptors (rods and cones) and second-order cells (bipolar and horizontal cells) respond to light with graded potentials of complex waveform (Werblin and Dowling, 1969; Kaneko, 1970). One of the striking early observations in retinal physiology was that the graded potentials of photoreceptors and bipolar cells have a distinct sustained component that is present in some ganglion cells but disappears in On-Off ganglion cells. This signifies that the visual information encoded by graded potentials in the outer retina is decomposed and distributed among ganglion cells. The initial response to change in illumination is relayed to transient On-Off ganglion cells, whereas slower components are conveyed to sustained On and Off ganglion cells (Kuffler, 1953; Wunk and Werblin, 1979). Although observed for decades, the synaptic mechanisms of the transformation have remained elusive.

Previous studies suggest that inhibitory GABAergic and glycinergic feedback from amacrine cells truncates release from the bipolar cell terminals to generate phasic output signals (Tachibana and Kaneko, 1988; Lukasiewicz et al., 1994; Z hang and Slaughter, 1995; Dong and Werblin, 1998; Euler and Wässle, 1998; Lukasiewicz and Shields, 1998a,b; Maple and Wu, 1998). Blocking this feedback prolongs the responses of transient ganglion cells but does not convert them to sustained responses (Lukasiewicz et al., 1995; Bieda and Copenhagen, 2000) (but see Dong and Werblin, 1998). Thus, feedback inhibition from amacrine cells strongly modulates release from bipolar cell terminals and contributes to the kinetics of transient responses but is not the underlying mechanism generating these responses in ganglion cells.

Glutamate receptor desensitization is another factor that contributes to the dynamics of ganglion cell signals (Lukasiewicz et al., 1995). Light responses in ganglion cells are mediated by both

Received Feb. 14, 2000; revised July 5, 2000; accepted July 5, 2000.

This work was supported by National Eye Institute Grant EY05725. We thank Dr. Werblin's laboratory for assistance with the slice technique.

Correspondence should be addressed to Gautam Awatramani, Department of Physiology and Biophysics, 124 Sherman Hall, 3435 Main Street, Buffalo, NY 14214. E-mail: gba@acsu.buffalo.edu.

Copyright (C) 2000 Society for Neuroscience $0270-6474 / 00 / 207087-09 \$ 15.00 / 0$ transient On-bipolar cells, whereas sustained On-bipolar cells were significantly depolarized. Inorganic calcium channel blockers disclosed that these distinct On-bipolar responses were inherent to the bipolar cell and not attributable to synaptic feedback. CPPG had distinct effects on sustained and transient ganglion cells, similar to its action on bipolar cells. The antagonist depolarized and blocked the light responses of sustained ganglion cells. In transient ganglion cells, CPPG suppressed the On light response but did not depolarize the cell or block the Off light response. These results suggest that transient and sustained light responses in ganglion cells result from selective bipolar cell input and that these two fundamental visual channels originate at the dendritic terminals of bipolar cells.

Key words: retina; metabotropic glutamate receptors; on-bipolar; ganglion cell; CPPG; visual neuroscience
N-methyl-D-aspartate (NMDA) and AMPA kainic acid (KA) glutamate receptors (Massey and Miller, 1988; Mittman et al., 1990; Diamond and Copenhagen, 1993). AMPA/KA receptors are known to participate in the rapid activation and inactivation of glutamate-mediated synaptic transmission (Trussell et al., 1993), and receptor desensitization might account for transient responses. However, when AMPA/KA receptor desensitization was blocked with cyclothiazide, transient responses were prolonged but still distinct from sustained responses. Moreover, in the presence of both picrotoxin and cyclothiazide, light responses in ganglion cells remained transient (Lukasiewicz et al., 1995). Thus, although desensitization and inhibition play important roles in shaping light responses in ganglion cells, factors determining the sustained or transient nature of the response are still unclear.

Here we report that there are two groups of bipolar cells, one with transient light responses and the other with sustained responses. This suggests that the transient and sustained signals in ganglion cells originate in the light responses of bipolar cells. We also identify a specific antagonist, $(R S)$ - $\alpha$-cyclopropyl-4-phosphonophenylyglycine (CPPG), for the synaptic metabotropic glutamate receptor (mGluR) at On-bipolar cell dendrites. CPPG had a differential effect on transient and sustained bipolar cells, in each case mimicking the effect of steady light. This indicates that transient and sustained signals originate at the dendritic inputs to bipolar cells. Using this information, we assessed the contribution of these two groups of bipolar cells to ganglion cell light responses. The results indicate that sustained and transient signals in ganglion cells arise from distinct populations of bipolar cells.

\section{MATERIALS AND METHODS}

Slice preparation. Larval tiger salamanders (Ambystoma tigrinum) were obtained from Kons Scientific (Germantown, WI) and Charles Sullivan (Nashville, TN) and were kept in tanks maintained at $4^{\circ} \mathrm{C}$ on a $12 \mathrm{hr}$ light/dark cycle. Retinal slices were prepared as described by Wu (1987). All procedures were performed in accordance with the US Animal Welfare Act and the National Institutes of Health Guide for the Care and Use of Laboratory. Animals (publication 85-23) and were approved by the university Animal Care Committee. In dim red light, animals were decapitated and double-pithed, and the eyes were enucleated. Under these conditions rod responses are greatly compromised (Hensley et al., 1993). 
The retina was removed from the eyecup, placed on a $0.45 \mu \mathrm{m}$ membrane filter (Millipore, Bedford, MA) with the vitreal side down, and then sliced at $150-250 \mu \mathrm{m}$ intervals using a tissue slicer (Stoelting, Woods Lane, IL). A single slice was then transferred to the recording chamber and viewed under infrared light using a CCD camera attached to an upright Olympus Optical (Tokyo, Japan) IMT2 fluorescent microscope, equipped with a $40 \times$ water immersion lens (Zeiss, Thornwood, NY). This slice was continually bathed with control Ringer's solution containing (in $\mathrm{mM}$ ): 111 $\mathrm{NaCl}, 2.5 \mathrm{KCl}, 1.8 \mathrm{CaCl}_{2}, 1 \mathrm{MgCl}_{2}, 10$ dextrose, and 5 HEPES, buffered to $\mathrm{pH}$ 7.8. Using a gravity-fed perfusion system Ringer's solution could be exchanged with drug-containing solutions within 5-10 sec. CPPG and L-2-amino-4-phosphonobutyrate (AP4), obtained from Tocris (Ballwin, $\mathrm{MO}$ ), were prepared as $10 \mathrm{~mm}$ stock solutions and diluted to the desired concentration before the experiment. All other chemicals were obtained from Sigma (St. Louis, MO).

Whole-cell and perforated patch-clamp recordings. Most of the recordings were made using the whole-cell patch technique. Recordings from Onbipolar cells were obtained within 2 min of establishing whole-cell configuration. After this period the responses began to run down, and the cell was discarded. In the other cell types, whole-cell recordings were stable for longer periods (30-120 min). Cells were identified based on their appearance after staining with Lucifer yellow. To ensure that cell dialysis did not affect our observations, a few recordings were done in each cell type using the nystatin perforated patch technique. Whole-cell recordings were made using $\sim 5 \mathrm{M} \Omega$ electrodes containing (in $\mathrm{mM}$ ): $105 \mathrm{~K}$-gluconate, $5 \mathrm{KCl}$ $1 \mathrm{MgCl}_{2}, 0.2$ BAPTA, 10 HEPES, 4 ATP-Na, 0.5 GTP-Na 3 and $1 \%$ Lucifer yellow. The $\mathrm{pH}$ was adjusted to 7.4 with $\mathrm{KOH}$. The reversal potential for chloride $\left(E_{\mathrm{Cl}}\right)$ was calculated to be $-70 \mathrm{mV}$. The voltage- and current-clamp recordings were made with an Axopatch 200B amplifier (Axon Instruments, Foster City, CA). Analog signals were filtered at $1 \mathrm{kHz}$ and sampled at $2 \mathrm{kHz}$ with the Digitadata 1200 analog-to-digital board (Axon Instruments). Clampex8 (PClamp8; Axon instruments) was used to control the voltage command outputs, acquire data, and trigger the light stimulus. The light source was a Stanley red light-emitting diode (LED), which emitted $\sim 10{ }^{4}$ photons $/ \mu \mathrm{m}^{2}$ per second at $620 \mathrm{~nm}$ (Nygaard and Frumkes, 1982). The currents and voltages shown are raw data, and electrode junctional potentials and access resistances were not corrected.

Electroretinograms. Electroretinograms (ERGs) were recorded in the superfused salamander eyecup preparation, as described previously (Dick and Miller, 1985). Field potentials were recorded using a Ringer's filled, low-resistance $(\sim 1 \mathrm{M} \Omega)$ glass electrode. The location of the recording site was based on the polarity of the ERG components using conventions established previously (Dick and Miller, 1985). Signals were obtained using an AC amplifier (model 1800; A-M Systems) and cutoff $<0.1$ and $>50 \mathrm{~Hz}$. Signals were sampled at $100 \mathrm{~Hz}$ with the Digidata 1200 interface in a computer running pClamp software. Red LEDs were used to stimulate the retina.

\section{RESULTS}

\section{Sustained and transient On-bipolars cells}

Although bipolar cells are considered to respond to light with sustained graded potentials, most On-bipolar cells show some decay after the initial peak voltage response. Whole-cell recordings revealed stark differences in decay among On-bipolar cells. One group of On-bipolar cells, exemplified in Figure $1 A$, responded to the onset of light with a mean \pm SD peak depolarization of $\sim 27.3 \pm 7.4 \mathrm{mV}(n=6)$. This initial depolarization slowly decayed in time and reached a steady state level of $11 \pm 2.3 \mathrm{mV}$ above the dark resting potential $(39.2 \pm 6.8 \%$ of the peak response). A second set of On-bipolar cells, illustrated in Figure $1 B$, responded to a step of light with an initial depolarization of $19.3 \pm 4.9 \mathrm{mV}(n=$ 6) that rapidly decayed to a plateau level only $2.6 \pm 0.8 \mathrm{mV}$ above the dark resting membrane potential ( $14 \pm 4.1 \%$ of peak response). The time course of the decay of the voltage responses could be approximated by an exponential function as shown by the dark lines in Figure 1, $A$ and $B$. The first group of bipolar cells had a mean decay time constant $(\tau)$ of $4019.4 \pm 1998.5 \mathrm{msec}$, whereas the second group had a considerably shorter mean $\tau$ of $408.6 \pm 81.3$ msec $(p<0.005$, Student's $t$ test; Fig. $1 F)$. There was also a small difference in the mean latencies of the two groups of bipolar cells. The mean latency of the first group of cells was $98.8 \pm 6.4 \mathrm{msec}$, whereas that of the second set of bipolar cells was $92.7 \pm 23.5 \mathrm{msec}$. However these latency differences were not statistically significant $(p>0.05)$. As might be expected, the time to peak of the second set of bipolar cells was shorter $(233.4 \pm 45.5$ vs $337.5 \pm 56.8 \mathrm{msec}$; $p<0.05)$. These data are summarized in Figure $1 E$.

When On-bipolar cells were clamped at $-70 \mathrm{mV}$, near the calculated chloride equilibrium potential, the light-evoked synaptic excitatory currents were found to be more transient than the
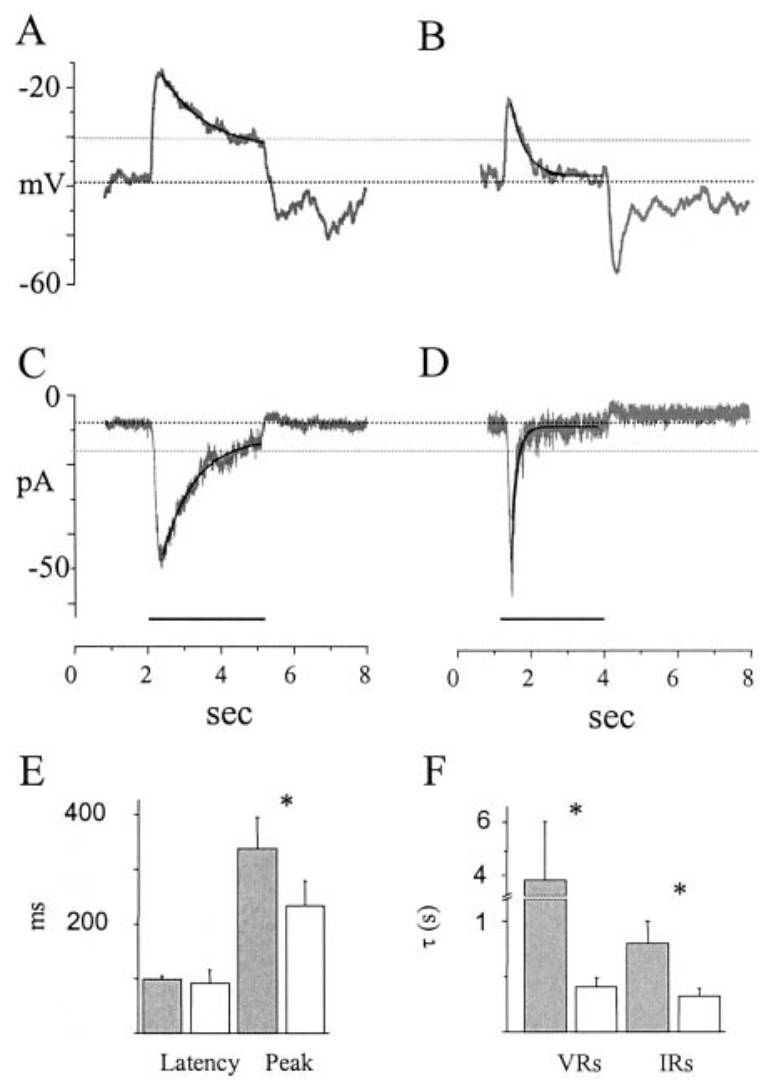

Figure 1. On-bipolar cells fall into two groups based on the temporal characteristics of their response to step illumination. $A, B$, Current-clamp records of the light-evoked EPSPS in sustained $(A)$ and transient $(B)$ On-bipolar cells. $C, D$, Light-evoked excitatory currents in the same two bipolar cells, voltage-clamped at $-70 \mathrm{mV}\left(\mathrm{Cl}^{-}\right.$reversal). The solid bar represents the light stimulus. $E$, The latencies for the two types of Onbipolar cells were similar, but the sustained On-bipolar cells had longer times to peak $(337.5 \pm 56.8$ vs $233.4 \pm 45 \mathrm{msec})$. The mean $+\mathrm{SD}$ of the latency and time to peak of the light-evoked EPSPs are plotted. $\left({ }^{*} p<\right.$ $0.005)$. Using PClamp software, the voltage and current responses were fit to single exponential functions (as shown by the dark curve overlaying the data traces in $A-D)$. $F$, The mean $\tau$ values for the decay of sustained versus transient voltage responses (VRs) were 4019 and $409 \mathrm{msec}$, respectively. The mean $\tau$ values for the decay of sustained versus transient current responses (IRs) were 802 and $320 \mathrm{msec}$, respectively. Sustained bipolar cells data are represented by gray bars; transient bipolar cells are represented by white bars.

corresponding voltage responses (Fig. $1 C, D$ ). However, the Onbipolar cells with more prolonged graded potentials also had more prolonged synaptic currents. The time course of the decay of the light-evoked currents could also be approximated by an exponential function (Fig. 1C,D, dark curves). The current responses decayed with a mean $\tau$ of $802 \pm 198$ msec for the first group of cells and $320 \pm 73 \mathrm{msec}$ for the second group of cells $(p<0.05$; see Fig. $3 F)$.

Although most experiments were performed using a red light stimulus applied on a dark background, in a few cells $(n=6)$ green adapting light was used. This background light was used to eliminate rod contributions to the bipolar cell response and also to determine whether retinal adaptation contributed to the transientsustained dichotomy that we observed. When the light response of bipolar cells was compared under a dark background and again under a green light background, the temporal characteristics were only slightly changed. Thus, sustained and transient responses were not caused by selective cone and rod input, as reported in fish (Saito and Kujiraoka, 1982). These results are consistent with another recent study (Roska et al., 2000) and indicate that transient responses are not simply the result of light adaptation.

Another distinguishing feature of these two types of On-bipolar cell was the hyperpolarizing Off light response. It was observed that cells with long decay constants also had slower, less pronounced Off 
A

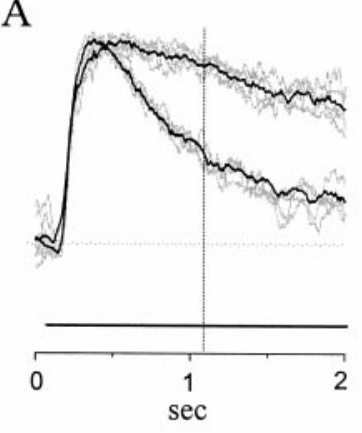

$\mathrm{C}$
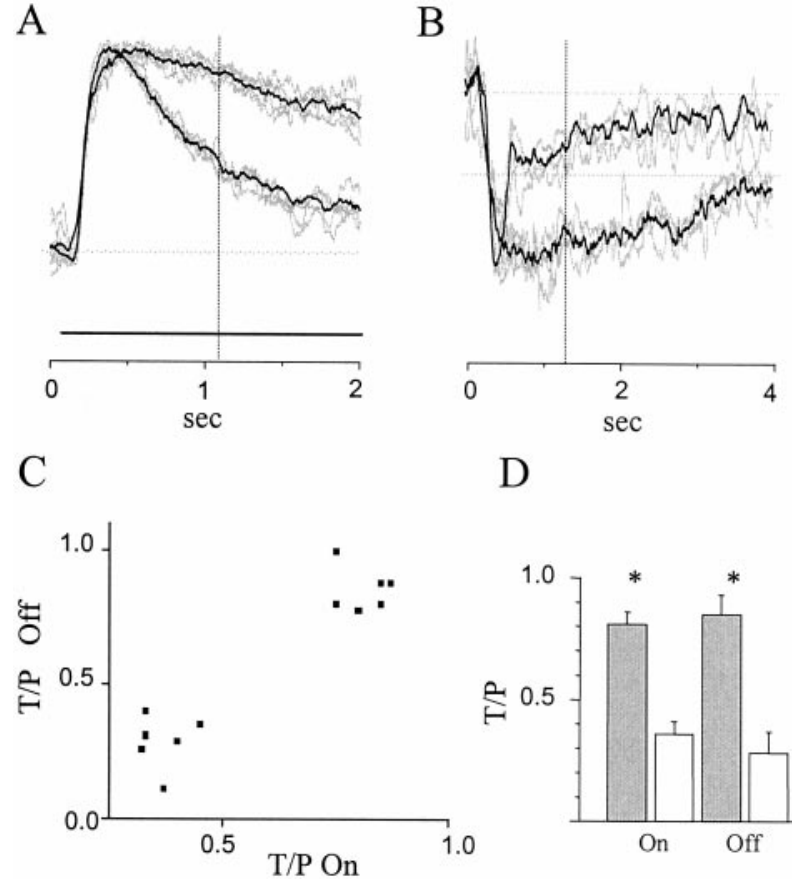

$\mathrm{D}$

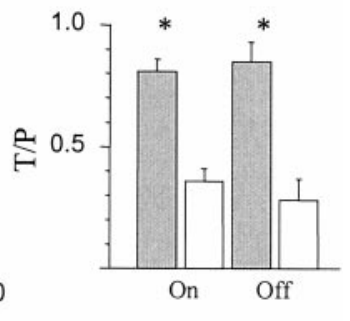

Figure 2. Normalizing On-bipolar light responses revealed two nonoverlapping sets of responses. $A$, The responses at light onset of 12 On-bipolar cells were normalized to their peak voltages, and the responses were superimposed. $B$, Similarly, the responses at light offset were normalized and superimposed. $C$, The ratio of the voltage amplitudes at the point marked by the dotted lines in $A$ and $B$ relative to the peak amplitudes was plotted for each On-bipolar cell. $D$, The mean tonic-to-phasic ratios at light onset and offset are graphed for the sustained (dark bars) and transient (light bars) cells for both the On and Off responses.

responses than cells with short decay constants (Fig. 1, compare $A$, $B)$. In the former group, this afterhyperpolarization had a mean maximum amplitude of $14.33 \pm 4.13 \mathrm{mV}(52 \%$ of peak On response), peaked at $\sim 1 \mathrm{sec}$, and decayed to the dark potential $\sim 5$ sec after the termination of the stimulus. In contrast, in the latter group, a transient Off hyperpolarization of $\sim 17.42 \pm 5.5 \mathrm{mV}$ occurred at light offset ( $90.4 \%$ of peak On response). This afterhyperpolarization consisted of two components: a transient fast component that peaked 224.6 \pm 10.24 msec after the offset of the stimulus and a second more sustained component that decayed to the dark potential within 5-7 sec. In voltage-clamp recordings, the Off responses were much less pronounced. Part of the reason might be that the current is small in voltage clamp. Additionally, voltagegated conductances may play an important role in shaping this response.

Analysis of the responses of all On-bipolar cells studied indicated that they fell into two categories. When the peak amplitudes of the On response were normalized and superimposed, the traces fell into two nonoverlapping groups as shown in Figure $2 A$. Similar analysis of the Off hyperpolarization also revealed two groups (Fig. $2 B)$. As another means of measuring the decay of bipolar cells responses, the ratio of the amplitude of the response $1 \mathrm{sec}$ after the onset of the light to the peak response was computed. This ratio gives a measure of the rate of decay, as well as the relative magnitude of the sustained component. This is graphed as the tonic-to-phasic ratio $(\mathrm{T} / \mathrm{P})$ in Figure $2 D$. In cells with long decay constants (gray bars), the mean $\mathrm{T} / \mathrm{P}$ was $0.811 \pm 0.05$ for the On voltage responses and $0.85 \pm 0.08$ for the Off responses. In contrast, cells with short decay constants (white bars) had average $\mathrm{T} / \mathrm{P}$ values of $0.36 \pm 0.05$ and $0.28 \pm 0.09$ for the On and Off responses, respectively. When the $\mathrm{On}$ and $\mathrm{Off} \mathrm{T} / \mathrm{P}$ values were plotted against each other, the cells fell into two distinct groups (Fig. 2C). Bipolar cell responses with phasic On components also had transient Off responses. Conversely, cells with more tonic On responses had sustained Off responses.
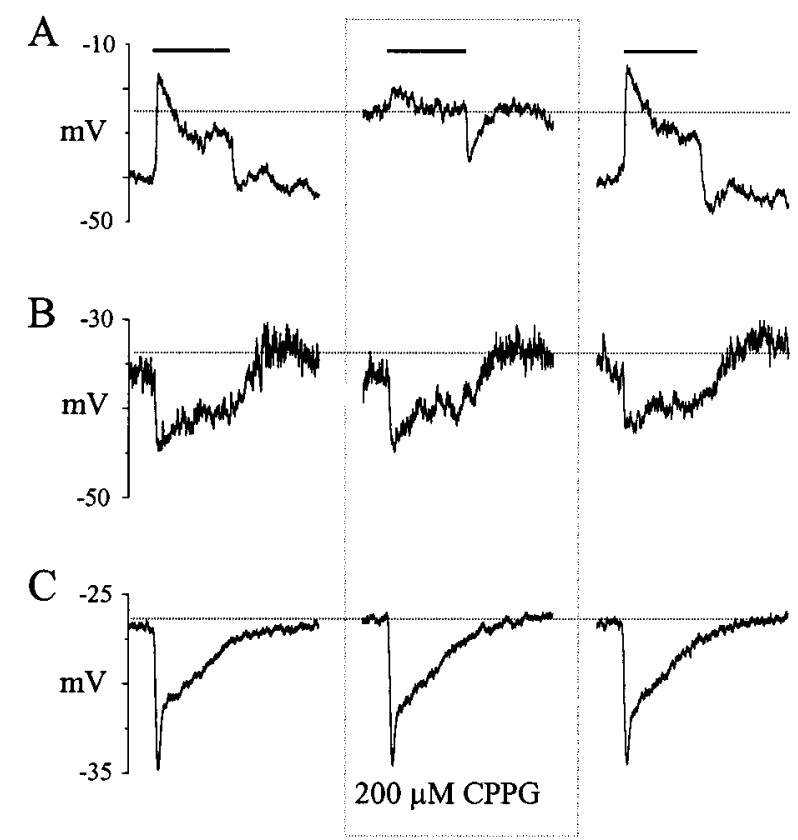

Figure 3. Effects of CPPG on the light-evoked EPSPs in the outer retina. $A$, CPPG suppressed the light response of an On-bipolar cell. CPPG has no significant effect on the light-evoked potentials of an Off-bipolar cell $(B)$ or a rod photoreceptor $(C)$. Whole-cell recordings of neurons in control Ringer's solution (left), then in the presence of CPPG (middle), and after the mGluR antagonist has been washed out (right) are shown. The solid bar represents a $5 \mathrm{sec}$ light stimulus.

Visualization of the morphology of a few On-bipolar cells, using Lucifer yellow, suggested distinct differences in the axonal arborization of transient $(n=7)$ and sustained $(n=2)$ bipolar cells. In transient On-bipolar cells, the axonal terminals ramified in the middle of the inner plexiform layer, whereas in sustained Onbipolar cells the arborization was more proximal. On the basis of these anatomical distinctions and the discrete decay kinetics of the light responses at both onset and offset of the light stimulus, On-bipolar cells were parsed into two groups: sustained and transient.

From these observations it is reasonable to conclude that transient and sustained responses of ganglion cells are the result of segregated inputs from the two types of bipolar cell. We found an antagonist of the On-bipolar metabotropic receptor that allowed us to confirm this supposition. Furthermore, if bipolar cells are inherently either transient or sustained, then this raises a question about the mechanism that initiates this distinction. It might be attributable to the temporal properties of photoreceptor transmitter release or to response kinetics of bipolar cell synaptic transduction. The metabotropic receptor antagonist revealed that On-bipolar response kinetics depends on the latter and not on temporal properties of photoreceptor release. Before addressing these two points, the properties of the metabotropic glutamate receptor need to be described.

\section{CPPG: an antagonist at the AP4 receptor}

In the dark, glutamate released by photoreceptors activates mGluRs on the dendritic terminals of On-bipolar cells. These receptors are negatively coupled to a cationic conductance; thus glutamate hyperpolarizes On-bipolar cells. At the onset of light, photoreceptors hyperpolarize and stop releasing glutamate, and consequently On-bipolar cells depolarize. Figure $3 A$ shows a current-clamp recording of the light-evoked EPSP in an On-bipolar cell obtained in dark-adapted retinal slice preparation. The dark potential of this cell was approximately $-40 \mathrm{mV}$, and a $5 \mathrm{sec}$ light stimulus evoked an initial peak followed by a smaller, sustained depolarization. At the offset of the light stimulus, the membrane potential returned to the dark resting level. Application of $200 \mu \mathrm{M}$ 
Figure 4. CPPG antagonized and reversed the effects of AP4 on On-bipolar cells. $A$, Light-evoked EPSPs in an On-bipolar cell in control, in the presence of $2 \mu \mathrm{M}$ AP4, in the presence of $2 \mu \mathrm{M}$ AP4 $+200 \mu \mathrm{M}$ CPPG, and after the drugs had been washed out (left to right). The solid bar represents a $4 \mathrm{sec}$ light stimulus. $B$, The same cell was voltage-clamped from -120 to $-20 \mathrm{mV}$ in $25 \mathrm{mV}$ steps for $50 \mathrm{msec}$. Each trace was separated by $1 \mathrm{sec}$ during which the cell was held at $-70 \mathrm{mV}$. Membrane currents in this cell are shown in control Ringer's solution (left), in response to AP4 (middle), and in the presence of AP4 + CPPG (right). Currentvoltage relationships shown in $C$ were calculated by subtracting the control current-voltage relationship from those obtained in the presence of the drugs (squares, AP4 data; circles, CPPG + AP4 data). Lines are a linear fit to the data points using PClamp software.
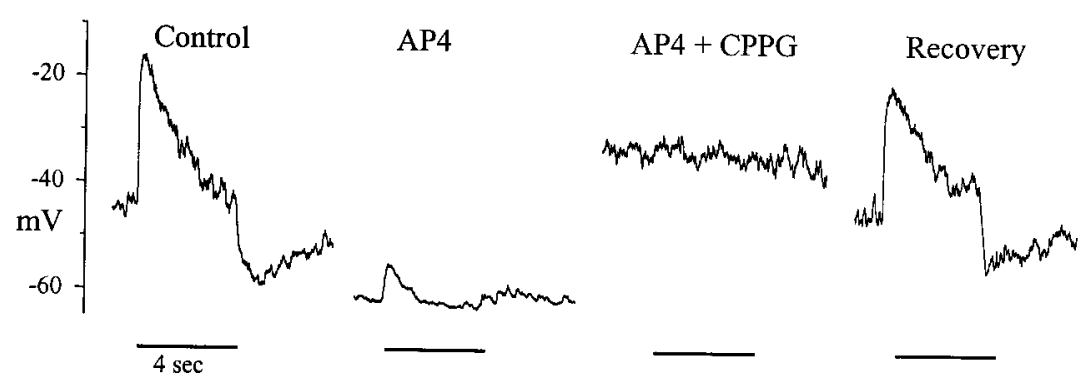

B
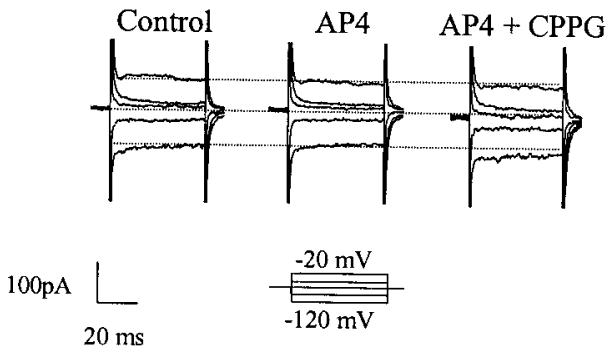

$\mathrm{C}$

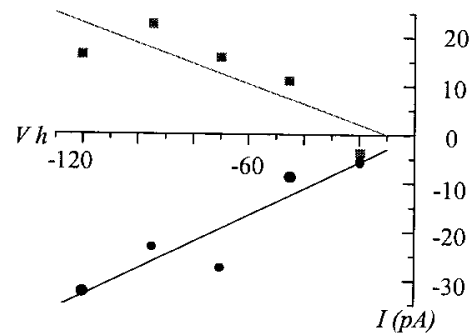

CPPG depolarized this On-bipolar cell to approximately $-25 \mathrm{mV}$, a few millivolts above the sustained level of the light response. Although CPPG depolarized the On-bipolar cell and suppressed its response to the onset of light, a large hyperpolarizing transient at light offset was often observed. This offset response was not blocked by picrotoxin and strychnine and had a reversal near $0 \mathrm{mV}$ (data not shown). The offset probably represents a peak of transmitter release from the photoreceptor as it depolarizes at light offset (Roska et al., 1998). Hence, $200 \mu \mathrm{M}$ CPPG inhibits the action of steady-state levels of glutamate released from the photoreceptors in the dark but is less effective in antagonizing higher levels of glutamate released initially at light offset. Because the effects of 200 $\mu \mathrm{M}$ CPPG were prominent and reversible, this concentration was used in this study. Moreover, at this concentration CPPG had negligible effects on the potential and light response of rod photoreceptors $(n=4$; Fig. $3 C)$ and Off-bipolar cells $(n=4$; Fig. $3 B)$ or the Off response of ganglion cells (see below), indicating that it specifically affected receptors on On-bipolar cells.

AP4 has often been used as a pharmacological tool to separate On and Off pathways in the retina (Slaughter and Miller, 1981). In the brain and spinal cord, group III mGluRs (mGluR4, 6, 7, and 8) are distinguished by their selective affinity for this drug. In the retina, AP4 mimics the effect of glutamate on the On-bipolar cells, suggesting that the On response is mediated via group III mGluRs. Confirming the pharmacological findings, molecular characterization of these receptors in mouse identified them as mGluR6 (Nakajima et al., 1993). To define the properties of CPPG, we tested its ability to antagonize the effects of AP4 on On-bipolar cells (Fig. $4 A)$. Application of $2 \mu \mathrm{M}$ AP4 hyperpolarized the membrane potential of the On bipolar cell, indicating that steady-state dark levels of endogenous glutamate did not saturate the mGluRs. Two micromolar AP4 almost completely suppressed the light-evoked response. Further application of $200 \mu \mathrm{M} \mathrm{CPPG}$ in the presence of $2 \mu \mathrm{M}$ AP4 antagonized and reversed the effects of AP4. CPPG produced a depolarization of the bipolar cell and a suppression of the light response. Note that CPPG depolarized this cell slightly beyond the voltage of the sustained light response. The effects of these drugs were reversible. Figure $4 B$, left, shows the $I-V$ relationship for the same On-bipolar cell. The cell was held at $-70 \mathrm{mV}$ and then stepped for a duration of $50 \mathrm{msec}$, from -120 to $-20 \mathrm{mV}$ in increments of $25 \mathrm{mV}$. These neurons exhibited both inward and outward rectification as noted previously (Lasater, 1988; Tian and Slaughter, 1994). The protocol was then repeated in the presence of
$2 \mu \mathrm{M}$ AP4 (Fig. 4B, middle). Consistent with current-clamp recordings, application of AP4 induced a small outward current. The ligand-gated current was small at each command potential and outweighed by the much larger, voltage-gated currents. Therefore, control currents were subtracted from the currents observed in the presence of AP4, thereby isolating the ligand-gated currents. The differences in current at various voltages, with and without AP4, are plotted in Figure $4 C$ (squares). The difference current revealed a net outward current that reversed near $-10 \mathrm{mV}$, confirming that AP4 closed a cationic channel (Shiells et al., 1981). When the same protocol was repeated in the presence of $200 \mu \mathrm{M} \mathrm{CPPG}$ and $2 \mu \mathrm{M}$ AP4, an inward current was observed (Fig. 4B, right). The difference in currents in the presence and absence of CPPG and AP4 was a net inward current that also reversed near $-10 \mathrm{mV}$ (Fig. $4 C$, circles). The results indicate that CPPG antagonized the action of endogenous glutamate as well as exogenously applied AP4. CPPG depolarized On-bipolar cells by opening a channel with a reversal potential near $-10 \mathrm{mV}$, which probably represents a nonspecific cation conductance.

Another method of measuring the effectiveness and specificity of CPPG is to examine the effects of this drug on the ERG in the intact eyecup preparation. The ERG is a field potential that consists of waveforms generated by neurons in the outer retina. The "b" wave of the ERG is thought to represent the field potential generated by the depolarization of On-bipolar cells (Stockton and Slaughter, 1989). Blocking the light-evoked depolarization of Onbipolar cells by applying AP4 completely eliminates the b wave, whereas the other components of the ERG remain intact (Gurevich and Slaughter, 1993). Figure $5 A$ compares the effects of CPPG with those of AP4 on the ERG. In these recordings the b wave was completely abolished by $50 \mu \mathrm{M}$ AP 4 and significantly reduced by CPPG $(500 \mu \mathrm{M})$. These results are consistent with the finding that both of these agents prevent the light-evoked depolarization of On-bipolar cells (Figs. 3, 4). The amplitude of the b wave, measured from the positive peak of the a wave to the negative peak of the b wave, was completely suppressed by AP4 $(n=4)$. Saturating doses ( $2 \mathrm{~mm}$ ) of CPPG maximally suppressed the b wave by $\sim 80 \pm$ $3 \%(n=4)$. Comparing various doses of CPPG indicated that the $\mathrm{IC}_{50}$ was $\sim 185 \mu \mathrm{M}$ (Fig. $5 B$ ). Drug concentrations in the retinal slice and the eyecup are not always comparable, because diff usion barriers in the eyecup often necessitate higher drug doses. Although CPPG suppressed the b wave, it left the a and d waves intact, indicating that its action was specific for the On-bipolar cells. 
A

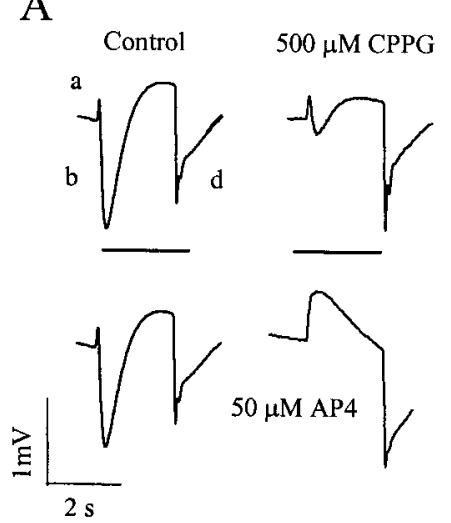

B

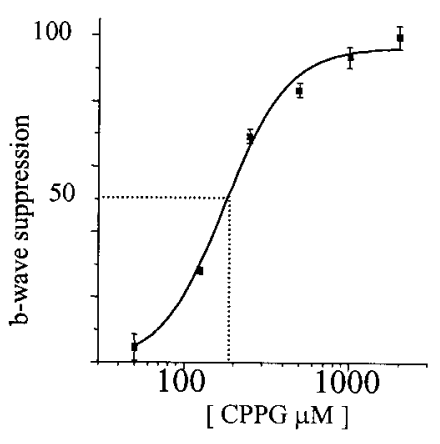

Figure 5. AP4 and CPPG suppress the b wave of the ERG. $A$, The ERG recorded in response to full-field light stimulation in control Ringer's solution (left) and in the presence of CPPG (right) is shown in the top panel. An ERG recorded in another eyecup in control (left) and in the presence of AP4 (right) is shown in the bottom panel. The solid bar represents a $2 \mathrm{sec}$ light stimulus. $B$, Dose-response curve for CPPG. Each point represents the mean \pm SEM percentage of the maximal suppression of the $b$ wave by CPPG (from 4 preparations). The data were fit to the logistic equation using Origin software.

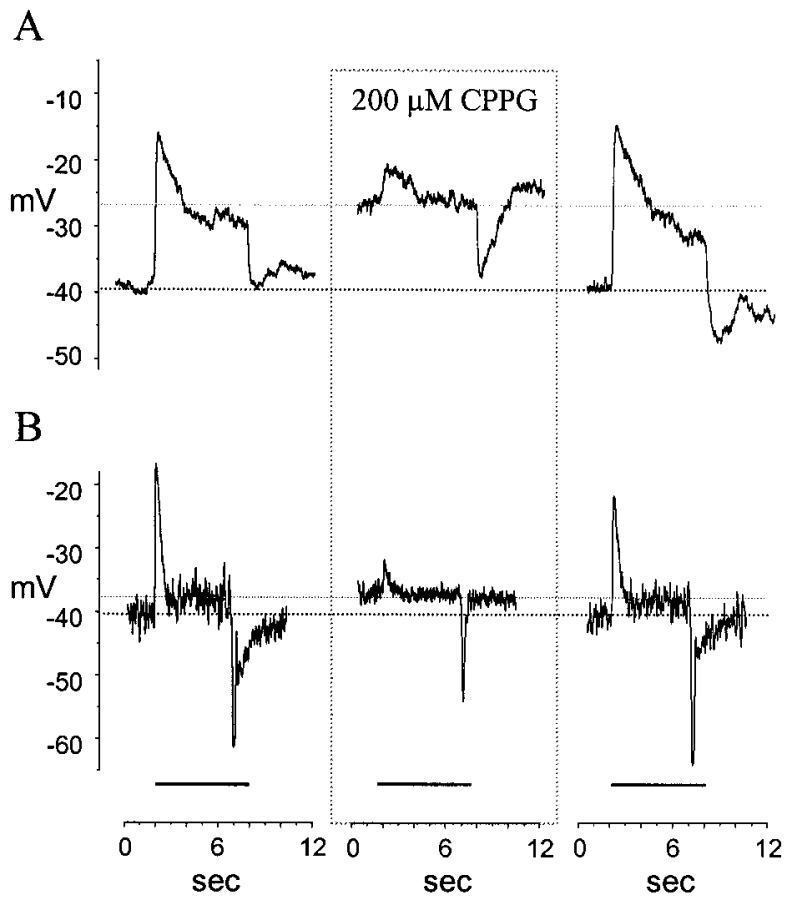

Figure 6. Differential effect of CPPG on sustained and transient Onbipolar cells. Responses of a sustained On-bipolar cell $(A)$ and transient On-bipolar cell $(B)$ in control, CPPG, and after the drug had been washed out (left to right) are shown.

Taken together, these results demonstrate that CPPG is a selective antagonist at the AP4-sensitive, group III mGluRs in the retina.

\section{Synaptic block depolarized sustained but not transient On-bipolar cells}

CPPG blocked the action of endogenous transmitter and depolarized the On-bipolar cell to a level slightly above the sustained phase of the light response. This phenomenon was observed in all Onbipolar cells tested. However, CPPG had different effects on sustained and transient bipolar cells because the amplitudes of their steady-state responses were different. This is illustrated in Figure 6. In the sustained On-bipolar cell, the peak light response amplitude was $25 \mathrm{mV}$, and the sustained response was $10 \mathrm{mV}$. CPPG depolarized the resting membrane potential by $12 \mathrm{mV}$ (dotted line). In the transient bipolar cell, CPPG suppressed most of the peak light response but only minimally depolarized the membrane potential. Hence, CPPG reproduced the action of maintained light in both types of bipolar cell.

CPPG evoked distinctly different responses in the two groups of bipolar cells, yet in both groups it was blocking the postsynaptic receptors at On-bipolar dendrites. This indicates that the steadystate responses that distinguish sustained and transient bipolar cells are not attributable to the release kinetics at photoreceptor terminals. However, these results do not exclude the possibility that synaptic feedback determines the steady-state voltage. Because CPPG caused a depolarization of some On-bipolar cells, it was conceivable that this activated neural circuits and provided inhibitory feedback to selectively truncate the responses of transient On-bipolar cells. To test this possibility, we examined the effects of blocking all synaptic transmission on the membrane potential of On-bipolar cells. Consistent with previous findings (Dacheux et al., 1979; Slaughter and Miller, 1981) $\mathrm{Cd}^{2+}$ depolarized and eliminated the light responses of On-bipolar cells (Fig. 7). $\mathrm{Cd}^{2+}$, like CPPG, significantly depolarized sustained On-bipolar cells but produced only a small depolarization in transient bipolar cells (Fig. $7 A, B)$. In every instance, $\mathrm{CPPG}$ and $\mathrm{Cd}^{2+}$ depolarized bipolar cells to a voltage just slightly more positive than the plateau voltage produced by maintained light stimulation. Figure $7 C$ plots the depolarizations produced by $\mathrm{CPPG}$ and $\mathrm{Cd}^{2+}$ against the sustained phase of the light responses of On-bipolar cells, showing that these blockers mimic the sustained phase of the light response. The $\mathrm{Cd}^{2+}$ results confirm the CPPG findings and furthermore indicate that the steady-state voltages in the two sets of bipolar cells are intrinsic to the bipolar cell and not attributable to synaptic feedback.

\section{Sustained and transient ganglion cell light responses}

With knowledge of these distinct effects of CPPG on the membrane potential of sustained and transient On-bipolar cells, it would be anticipated that CPPG would hold sustained On-bipolar cells in a depolarized state that would favor transmitter release but would hold transient On-bipolar cells near their dark resting state, which would prevent transmitter release. We therefore examined the ramifications of these effects of CPPG on the postsynaptic ganglion cells.

At the onset of a light, some ganglion cells responded with a transient depolarization that returned to the dark potential in the presence of the light stimulus (Fig. 8A). Other ganglion cells responded with a transient depolarization that was followed by a sustained depolarization that persisted for the duration of the light stimulus (Fig. 8B). The synaptic currents reflected a similar distinction in the relative amplitude of the peak and the plateau currents (Fig. 8C,D). This dichotomy seemed to reflect the properties of the two groups of On-bipolar cells. When transient ganglion cells were stained with Lucifer yellow $(n=6)$, their dendritic processes were found to terminate near the middle of the inner plexiform layer. The dendrites of sustained ganglion cells $(n=2)$ ramify at the border of the inner plexiform layer. This anatomical separation has been described in rabbit retina, where transient ganglion cells terminate in the middle of the inner plexiform layer, whereas sustained ganglion cells ramify at the edges of this plexiform layer (Roska and Werblin, 2000). This distribution of transient and sustained ganglion cell processes correlates with the axonal terminations of transient and sustained bipolar cells, respectively.

Figure $9 A$ shows a transient ganglion cell that responded to a 6 sec light stimulus with $\sim 35 \mathrm{mV}$ EPSPs at light onset and offset. When $200 \mu \mathrm{M}$ CPPG was applied, the On EPSP was suppressed significantly, but the resting membrane potential and the Off EPSP were only slightly affected. The simplest explanation for this outcome is that CPPG acted directly and selectively to suppress transient On-bipolar input to this ganglion cell. After removal of CPPG the light responses recovered. A similar observation was made when the ganglion cell was voltage-clamped at $-70 \mathrm{mV}$. 
A

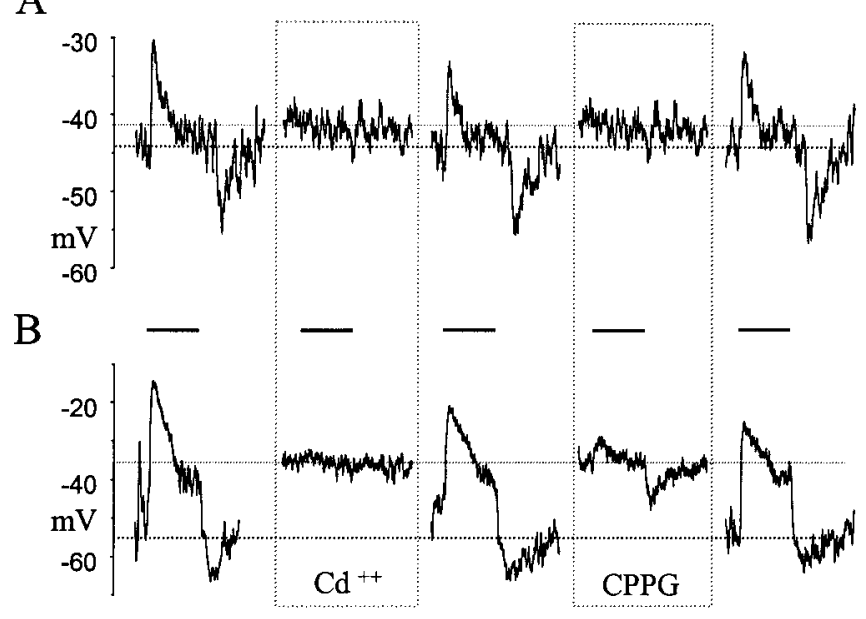

$\mathrm{C}$

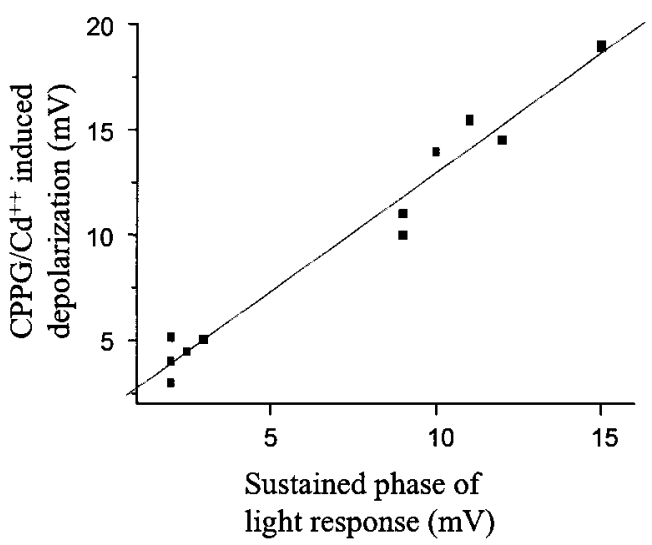

Figure 7. Similar effects produced by blocking glutamate transmission presynaptically and postsynaptically. $A$, Plot of light response of a transient On bipolar cell under control conditions, during application of $50 \mu \mathrm{M}$ cadmium, after recovery from cadmium, during application of $200 \mu \mathrm{M} C P P G$, and after recovery from CPPG. The dark bars under the voltage traces indicate the timing of a 5 sec light stimulus. $B$, Same protocol as in $A$ but while recording from a sustained On-bipolar cell. $C$, Plot of the depolarization produced by CPPG and cadmium versus the sustained depolarization during the light response of On-bipolar cells.

A

B

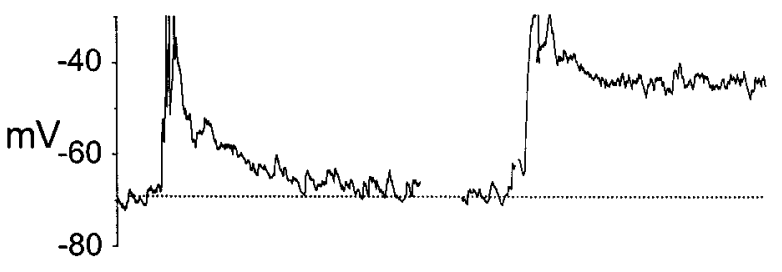

$\mathrm{C}$

D
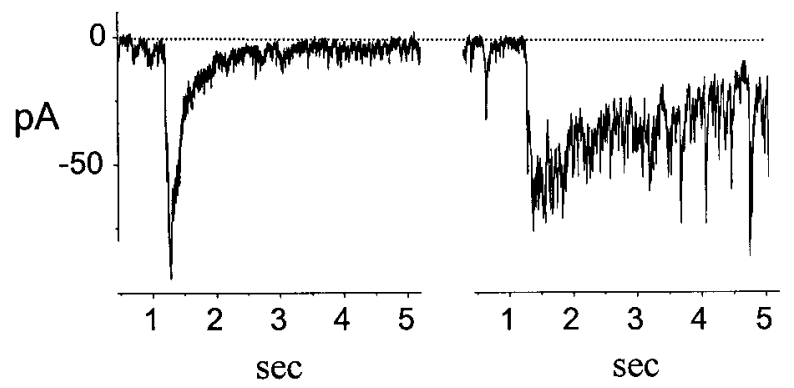

Figure 8. Light responses of transient and sustained ganglion cells. $A, C$, Voltage and current recordings from a transiently responding ganglion cell. Note the responses return to resting levels while the light is still on. $B, D$, Voltage and current responses in a ganglion cell that responds in a more sustained manner $\left(\mathrm{V}_{\text {hold }},-70 \mathrm{mV}\right)$.

Under control conditions there were large On and Off EPSCs, which decayed back to baseline during the light stimulus. CPPG suppressed the On EPSP but did not significantly alter the holding current, and the Off EPSC remained. Figure 9, $C$ and $D$, shows continuous traces of the membrane potential and the membrane current while a different transient ganglion cell was recorded in the dark. When CPPG was applied, it increased the spontaneous activity in this ganglion cell but had only a small effect on the baseline voltage or current. Similar results were observed in 12 other transient ganglion cells. This correlates well with the effect of CPPG on transient bipolar cells, in which the light responses were suppressed attendant with a small depolarization of the resting potential.

Application of CPPG had a different effect on sustained Onganglion cells as illustrated in Figure 10. Figure $10 \mathrm{~A}$ shows the voltage response of a ganglion cell to a $6 \mathrm{sec}$ light stimulus. There was an initial peak depolarization of $38 \mathrm{mV}$ followed by a sustained depolarization of $23 \mathrm{mV}$. When $200 \mu \mathrm{M}$ CPPG was applied, the cell depolarized by $30 \mathrm{mV}$, and all light responses were abolished. The membrane potential and light responses of the cell returned when CPPG was removed. Similar observations were made when the cell was voltage-clamped at $-70 \mathrm{mV}$. Under control conditions there was a large peak current a light onset, followed by a smaller sustained current that persisted for the duration of the light response. When CPPG was applied, it produced a standing inward current and suppressed the On-response but left the Off response. The effect of CPPG on the resting potential of sustained cells is illustrated in Figure 10, $C$ and $D$. When the cell potential was monitored in the dark, CPPG caused a depolarization of $30 \mathrm{mV}$, and this reversed as the antagonist was washed out. CPPG produced a concomitant inward current of $\sim 30 \mathrm{pA}$. Similar results were found in 10 other sustained ganglion cells. These observations correlate with the effect of CPPG on sustained bipolar cells.

In some ganglion cells, such as that illustrated in Figure 10, CPPG had an effect on the Off response. This is not unexpected, because CPPG depolarization of sustained bipolar cells will result in excitation of sustained amacrine cells. These inhibitory amacrine cells can affect the Off pathway. In support of this explanation, preliminary experiments indicate that glycine and GABA antagonists (strychnine, picrotoxin, and CGP35348) eliminated most of the effect of CPPG on the Off-response in ganglion cells.

\section{DISCUSSION}

\section{Pharmacological properties of AP4-sensitive mGluRs in the retina}

The synaptic receptor at the On-bipolar cell dendrite was the first mGluR to be described (Shiells et al., 1981; Slaughter and Miller, 1981; Nawy and Jahr, 1990). Yet it has proven difficult to find a selective antagonist for this receptor. Although retinal AP4sensitive receptors are pharmacologically similar to other group III receptors in their sensitivity to various agonists (Slaughter and Miller, 1985; Thoreson and Miller, 1993; Tian and Slaughter, 1994), the mGluR antagonists $(S)$-2-amino-2-methyl-phosphonobutanoic acid and $(R S)$ - $\alpha$-methyl-4-carboxyphenylglycine had little effect on these receptors (Thoreson et al., 1995, 1997; Dixon and Copenhagen, 1997). Other phenylglycine derivatives, such as $S$-4-carboxy3-hydroxyphenylglycine, $S$-3-carboxy-4-hydroxyphenylglycine, and $S$-4-carboxyphenylglycine, which are known to antagonize group III receptors, were found to act as agonists at the AP4-sensitive receptor in the retina (Thoreson et al., 1995). (RS)-4-Chloro-3,5dihydroxphenylglycine and $(R S)-3,4,5$-trihydroxphenylglycine were 
A

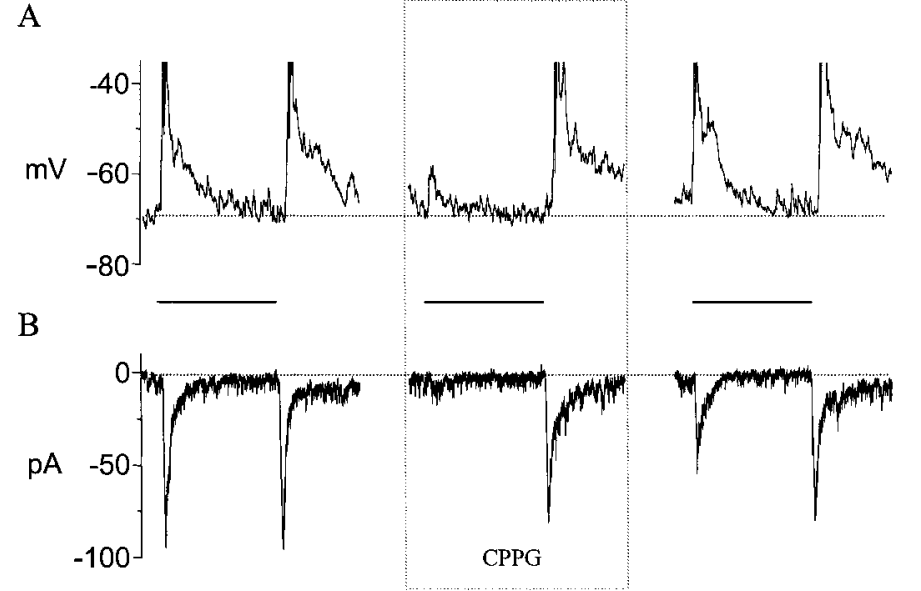

C

$\mathrm{D}$

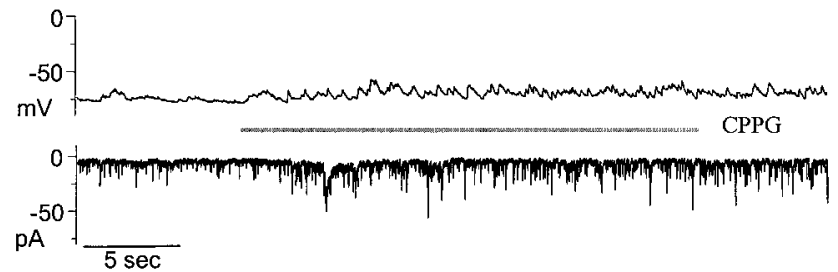

Figure 9. Effect of CPPG on a transient ganglion cell. $A, B$, The lightevoked EPSP and EPSCs $\left(\mathrm{V}_{\text {hold }},-70 \mathrm{mV}\right)$ of a transient ganglion cell in control solution, in the presence of $200 \mu \mathrm{M} \mathrm{CPPG}$, and after the drug had been washed out. The three bars between $A$ and $B$ indicate the timing of the light stimuli. $C$, Effect of CPPG (bar) on the membrane potential of a transiently responding ganglion cell. $D$, Effect of CPPG on the membrane current of the same cell $\left(\mathrm{V}_{\text {hold }},-70 \mathrm{mV}\right)$.

shown to have some antagonistic activity at retinal mGluRs, but these drugs had low potency and little specificity (Thoreson et al., 1997). The inability to find a specific antagonist to AP4-sensitive receptors has hampered the functional study of this receptor in the retina. CPPG is severalfold more potent than the previously described mGluR antagonists and is found to antagonize the inhibitory effects of AP4 on synaptic transmission in the spinal cord (Jane et al., 1996), cerebral cortex (Toms et al., 1996), rat taste cells (Lin and Kinnamon, 1999) and the neurons of the auditory system (von Gersdorff et al., 1997). In this study we identify CPPG as the first specific antagonist at the retinal mGluR on the On-bipolar cell.

In the retina, light reduces photoreceptor transmitter release and depolarizes On-bipolar cells. Similar to the action of light, CPPG caused an increase in membrane conductance and a depolarization of sustained On-bipolar cells. The membrane potentials of rod photoreceptors and Off-bipolar cells were not blocked by CPPG. Although we did not record from cones, the responses of Offbipolar cells and the $\mathrm{d}$ wave of the ERG in the light-adapted retina imply that cone responses were intact. Thus, CPPG specifically blocks the action of glutamate on mGluRs in On-bipolar cells but does not affect its release from photoreceptors or its action on the ionotropic receptors in the Off-bipolar cells. Consistent with CPPG being a group III antagonist in other parts of the CNS (Jane et al., 1996), it reversed the hyperpolarizing effects of the group III mGluR agonist AP4. More evidence to support the role of CPPG as an mGluR antagonist that affects On-bipolar cells comes from recordings of light-evoked intraretinal field potentials (ERGs) in the intact eyecup. In the ERG, the b wave represents the lightevoked electrical activity of the On-bipolar cells (Stockton and Slaughter, 1989), whereas the d wave reflects activity of Off-bipolar cells (Xu and Karwoski, 1995). The suppression of the b wave and not the $\mathrm{d}$ wave by CPPG supports the hypothesis that it specifically disrupts the light responses of On-bipolar cells. Last, most ganglion cells receive excitatory inputs from On- and Off-bipolar cells, and these inputs give rise to On and Off responses, respectively. CPPG blocked the On response in ganglion cells, but the Off response

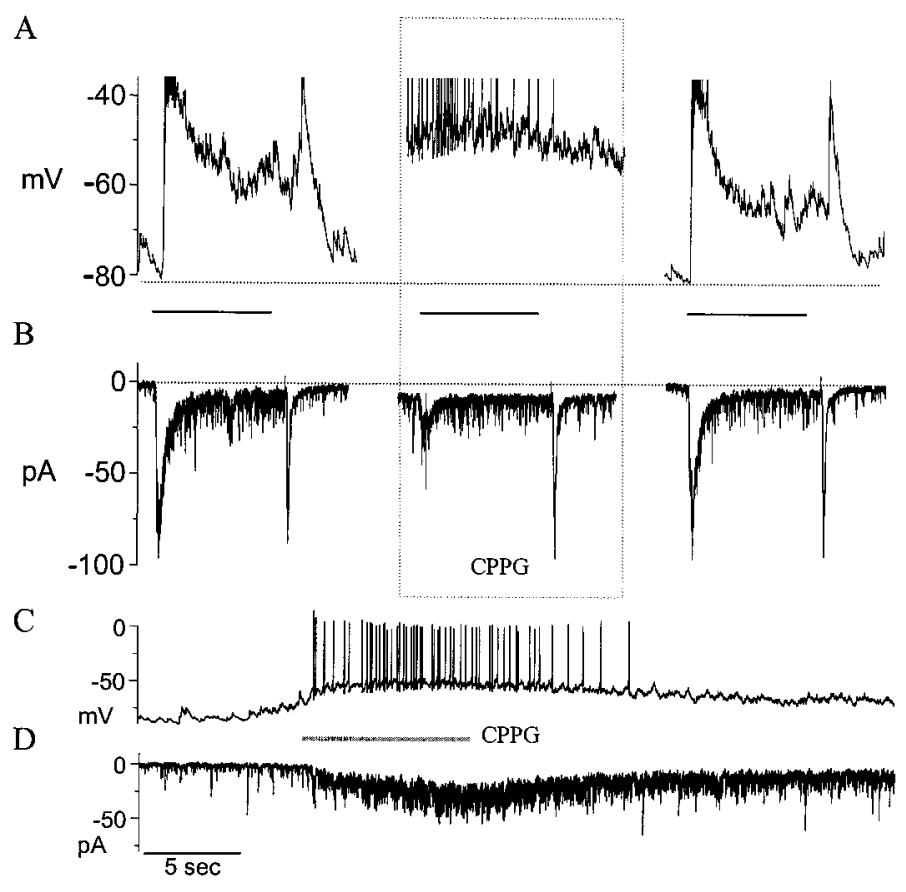

Figure 10. Effect of CPPG effect on a sustained ganglion cell. $A, B$, The light-evoked EPSPs and EPSCs of a sustained ganglion in control solution, in the presence of $200 \mu \mathrm{M} C P P G$, and after the drug has been washed out. The three bars between $A$ and $B$ indicate the timing of the light stimuli. $C$, Effect of CPPG (bar) on the membrane potential of a sustained responding ganglion cell. $D$, Effect of CPPG on the membrane current of the same cell $\left(\mathrm{V}_{\text {hold }},-70 \mathrm{mV}\right)$.

remained relatively intact. Taken together these results demonstrate that CPPG specifically blocks the action of glutamate at On-bipolar mGluRs.

\section{Temporal characteristics of the light responses of On-bipolar cells}

On the basis of a number of criteria, On-bipolar cell responses fall into two groups: transient and sustained. First, light response decay time constants parse into two distinct domains. Second, the tonicto-phasic ratios in current clamp or voltage clamp place bipolar cells in two groups. Additionally, in transient bipolar cells, the undershoot of the voltage response at light offset has a fast component that is easily distinguishable from the slow undershoot observed in sustained cells. Figures 1 and 2 tabulate these differences, manifesting that there are two types of On-bipolar cells. Last, cell staining indicates that transient and sustained On-bipolar cells are morphologically distinct, with the axon processes of the former ramifying near the middle of the inner plexiform layer and the latter terminating more proximally in the inner plexiform layer.

$\mathrm{Wu}$ et al. (2000) have recently produced a catalog of 12 bipolar cell subclasses based on correlates between light responses and morphology. The transient cells in our experiments appeared similar to their cell types 7 and 8, whereas sustained cells resembled cell types 9 and 10. They did not report kinetic differences between these subclasses, although several laboratories have recently reported transient and sustained bipolar cells (Euler and Masland, 2000; Roska et al., 2000).

Besides different response kinetics, these two types of Onbipolar cell also respond differently to presynaptic or postsynaptic blockade of the action of glutamate. Blocking the release of glutamate with $\mathrm{Cd}^{2+}$ or antagonizing the postsynaptic mGluRs using CPPG caused On-bipolar cells to depolarize slightly above the plateau phase of their light response. Sustained bipolar cells depolarized to $\sim 39 \%$ of their peak response, whereas transient bipolar cells depolarize to $14 \%$ of their peak light response. It is interesting to note that although the peak depolarization of the On-bipolar cell corresponds to minimal glutamate released by photoreceptors, yet 
completely blocking glutamate release or antagonizing the mGluR did not depolarize these cells to this peak potential. In fact, blocking the action of glutamate mimicked the sustained phase of the light response, not the early transient component. One interpretation of these data is that the transient component of the cationic conductance desensitizes after prolonged activation. Because of the relatively slow application of $\mathrm{Cd}^{2+}$ or CPPG, the activation and desensitization processes occur in tandem during drug application, resulting in a depolarization to the plateau level. Moreover, $\mathrm{Cd}^{2+}$ blocks all light responses and all inhibitory neural feedback that is known to modulate these cells (Lukasiewicz and Werblin, 1994; Zhang and Slaughter, 1995; Dong and Werblin, 1998). Hence, the mechanisms underlying the modulation of the transient component appear to reside, at least in part, within the On-bipolar cell.

The signaling pathways in photoreceptors and On-bipolar cells may be analogous. In photoreceptor adaptation, calcium inhibits guanylate cyclase and thus modulates the responses of these cells (Matthews et al., 1988; Nakatani and Yau, 1988). If this is used as a model for bipolar cell response kinetics, then elevation of internal calcium during depolarization may serve as a negative feedback that reduces the On-bipolar cell light response. Consistent with this model, increasing internal calcium reduces the light responses of On-bipolar cells and occludes their light adaptation (Shiells and Falk, 1999). Hence, calcium influx through the cGMP-gated channel may initiate the decay of the On-bipolar cell light response. This internal feedback may be more pronounced in one type of On-bipolar cell, thereby accounting for transient responses.

Another potential contributor to the temporal responses in bipolar cells is the kinetics of glutamate in the synaptic cleft. But previous studies, using AMPA/KA receptor-mediated responses in horizontal cells as indicators of glutamate concentration in the synaptic cleft, suggested that glutamate levels decrease in a sustained manner in response to bright light (Gaal et al., 1998; Roska et al., 1998). Consistent with these findings, relatively sustained disfacilatory currents are observed in Off-bipolar cells (Maple et al., 1998; Roska et al., 2000). Because On- and Off-bipolar cells make similar contacts with photoreceptors (Lasansky, 1972), this would suggest that transient responses in On-bipolar cells are not shaped by the kinetics of photoreceptor transmitter release.

Voltage-sensitive channels may also contribute to the intrinsic differences between sustained and transient cells (Lasater, 1988; Mao et al., 1998; Euler and Masland, 2000). But we observed that the transient-sustained dichotomy remained under voltage clamp, negating an essential role for voltage-gated channels. Nevertheless, a much larger separation between sustained and transient Onbipolar responses was observed in current versus voltage clamp. Thus, voltage-gated channels may augment the transient-sustained dichotomy.

In addition to factors intrinsic to On-bipolar cells, it is important to acknowledge that extrinsic factors also contribute to the formation of transient bipolar cells responses. Probably the largest extrinsic factor is negative feedback from amacrine cells (Dong and Werblin, 1998), acting through $\mathrm{GABA}_{\mathrm{C}}$ receptors (Lukasiewicz et al., 1994).

\section{Origin of the transient and sustained light responses in ganglion cells}

The finding that CPPG significantly depolarized sustained but not transient On-bipolar cells allowed for the evaluation of synaptic input from these bipolar cells to ganglion cells. The prediction would be that ganglion cells that received input from sustained On-bipolar cells would depolarize in the presence of CPPG, whereas ganglion cells receiving input from transient bipolar cells would not. Our experiments disclosed that CPPP caused a depolarization in only sustained ganglion cells. This supported the conclusion that transient and sustained bipolar cells provide, respectively, the predominant input to transient and sustained ganglion cells. The similarity in dendritic ramifications in bipolar and ganglion cells with the same temporal properties provides an ana-

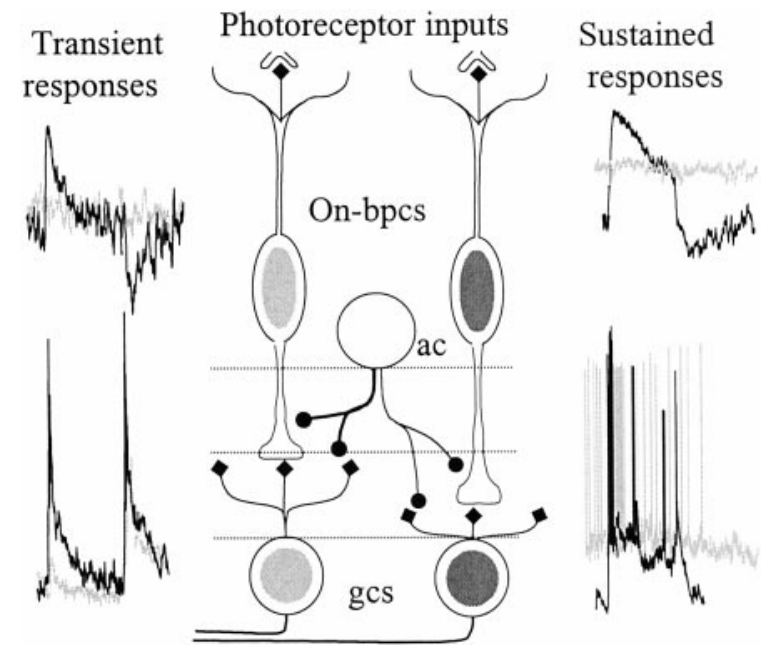

Figure 11. Model. Two separate channels, originating in bipolar cells, generate transient and sustained responses. The light responses of bipolar cells and ganglion cells are shown; the dark traces show voltage responses under control conditions, and the light traces show the responses in the presence of CPPG.

tomical substrate for this model. Hence the distinct temporal characteristics of the bipolar cells are faithfully conveyed and represented in phasic and tonic responses of ganglion cells (Fig. 11).

In addition to the nature of the synaptic input from bipolar cells, other factors contribute to the kinetics of light responses in ganglion cells. For example, AMPA receptor desensitization at ganglion cell dendritic terminals affects the time course of the light response (Lukasiewicz et al., 1995). Feed-forward inhibition is also known to contribute to the temporal properties of ganglion cells (Miller et al., 1981; Barnes and Werblin, 1987; Cook and McReynolds, 1998). In addition, voltage-gated channels may also play an important role in amplifying small input currents (Diamond and Copenhagen, 1995; Tabata and Ishida 1996). However, none of these factors is shown to be specific for transmission to sustained or transient ganglion cells. Hence the sustained-transient distinction seems to arise from different inputs to the ganglion cells, which are then shaped by these different factors.

Transient and sustained responses represent the extraction of discrete aspects of the visual world. The former convey information about motion and edge detection, whereas the latter relay signals associated with color and shape (Jacobs and Werblin, 1998; Boycott and Wassle, 1999). Therefore, the intricacies involved in the formation of these responses are not surprising. The present experiments indicate that this distinction first arises from the intrinsic properties of bipolar cells.

\section{REFERENCES}

Barnes S, Werblin F (1987) Direct excitatory and lateral inhibitory synaptic inputs to amacrine cells in the tiger salamander retina. Brain Res 406:233-237.

Bieda M, Copenhagen DR (2000) Inhibition is not required for the production of transient spiking responses form retinal ganglion cells. Vis Neurosci 17:243-254.

Boycott B, Wassle H (1999) Parallel processing in the mammalian retina: the Proctor Lecture. Invest Ophthalmol Vis Sci 40:1313-1327.

Cook PB, McReynolds JS (1998) Lateral inhibition in the inner retina is important for spatial tuning of ganglion cells. Nat Neurosci 1:714-719.

Dacheux RF, Frumkes TE, Miller RF (1979) Pathways and polarities of synaptic interactions in the inner retina of the mudpuppy: I. Synaptic blocking studies. Brain Res 161:1-12.

Diamond JS, Copenhagen DR (1993) The contribution of NMDA and non-NMDA receptors to the light-evoked input-output characteristics of retinal ganglion cells. Neuron 11:725-738.

Diamond JS, Copenhagen DR (1995) The relationship between lightevoked synaptic excitation and spiking behaviour of salamander retinal ganglion cells. J Physiol 487:711-725.

Dick E, Miller RF (1985) Extracellular K+ activity changes related to electroretinogram components. I. Amphibian (I-type) retinas. J Gen Physiol 85:885-909. 
Dixon DB, Copenhagen DR (1997) Metabotropic glutamate receptormediated suppression of an inward rectifier current is linked via a cGMP cascade. J Neurosci 17:8945-8954.

Dong CJ, Werblin FS (1998) Temporal contrast enhancement via GABAC feedback at bipolar terminals in the tiger salamander retina. J Neurophysiol 79:2171-2180.

Euler T, Masland RH (2000) Light-evoked responses of bipolar cells in a mammalian retina. J Neurophysiol 83:1817-1829.

Euler T, Wässle H (1998) Different contributions of GABAA and GABAC receptors to rod and cone bipolar cells in a rat retinal slice preparation. J Neurophysiol 79:1384-1395.

Gaal L, Roska B, Picaud SA, Wu SM, Marc R, Werblin FS (1998) Postsynaptic response kinetics are controlled by a glutamate transporter at cone photoreceptors. J Neurophysiol 79:190-196.

Gurevich L, Slaughter MM (1993) Comparison of the waveforms of the ON bipolar neuron and the b-wave of the electroretinogram. Vision Res 33:2431-2435.

Hensley SH, Yang XL, Wu SM (1993) Relative contribution of rod and cone inputs to bipolar cells and ganglion cells in the tiger salamander retina. J Neurophysiol 69:2086-2098.

Jacobs AL, Werblin FS (1998) Spatiotemporal patterns at the retinal output. J Neurophysiol 80:447-451.

Jane DE, Thomas NK, Tse HW, Watkins JC (1996) Potent antagonists at the L-AP4- and $(1 S, 3 S)$-ACPD-sensitive presynaptic metabotropic glutamate receptors in the neonatal rat spinal cord. Neuropharmacology $35: 1029-1035$.

Kaneko A (1970) Physiological and morphological identification of horizontal, bipolar, and amacrine cells in goldfish retina. J Physiol (Lond) 207:623-633.

Kuffler SW (1953) Discharge patterns and functional organization of mammalian retina. J Neurophysiol 16:37-68.

Lasansky A (1972) Cell junctions at the outer synaptic layer of the retina. Invest Ophthalmol 11:265-275.

Lasater EM (1988) Membrane currents of retinal bipolar cells in culture. J Neurophysiol 60:1460-1480.

Lin W, Kinnamon SC (1999) Physiological evidence for ionotropic and metabotropic glutamate receptors in rat taste cells. J Neurophysiol 82:2061-2069.

Lukasiewicz PD, Shields CR (1998a) A diversity of GABA receptors in the retina. Semin Cell Dev Biol 9:293-299.

Lukasiewicz PD, Shields CR (1998b) Different combinations of GABAA and GABAC receptors confer distinct temporal properties to retinal synaptic responses. J Neurophysiol 79:3157-3167.

Lukasiewicz PD, Werblin FS (1994) A novel GABA receptor modulates synaptic transmission from bipolar to ganglion and amacrine cells in the tiger salamander retina. J Neurosci 14:1213-1223.

Lukasiewicz PD, Maple BR, Werblin FS (1994) A novel GABA receptor on bipolar cell terminals in the tiger salamander retina. J Neurosci 14:1202-1212.

Lukasiewicz PD, Lawrence JE, Valentino TL (1995) Desensitizing glutamate receptors shape excitatory synaptic inputs to tiger salamander retinal ganglion cells. J Neurosci 15:6189-6199.

Mao BQ, MacLeish PR, Victor JD (1998) The intrinsic dynamics of retinal bipolar cells isolated from tiger salamander. Vis Neurosci 15:425-438.

Maple BR, Wu SM (1998) Glycinergic synaptic inputs to bipolar cells in the salamander retina. J Physiol (Lond) 506:731-744.

Massey SC, Miller RF (1988) Glutamate receptors of ganglion cells in the rabbit retina: evidence for glutamate as a bipolar cell transmitter. J Physiol (Lond) 405:635-655.

Matthews HR, Murphy RLW, Fain GL, Lamb TD (1988) Photoreceptor light adaptation is mediated by cytoplasmic calcium concentration. $\mathrm{Na}-$ ture 334:67-69.

Miller RF, Frumkes TE, Slaughter M, Dacheux RF (1981) Physiological and pharmacological basis of GABA and glycine action on neurons of mudpuppy retina. I. Receptors, horizontal cells, bipolars, and G-cells. J Neurophysiol 45:743-763.

Mittman S, Taylor WR, Copenhagen DR (1990) Concomitant activation of two types of glutamate receptor mediates excitation of salamander retinal ganglion cells. J Physiol (Lond) 428:175-197.

Nakajima Y, Iwakabe H, Akazawa C, Nawa H, Shigemoto R, Mizuno N, Nakanishi S (1993) Molecular characterization of a novel retinal metabotropic glutamate receptor mGluR6 with a high agonist selectivity for L-2-amino-4-phosphonobutyrate. J Biol Chem 268:11868-11873.

Nakatani K, Yau K-W (1988) Calcium and light adaptation in retinal rods and cones. Nature 334:69-71.

Nawy S, Jahr CE (1990) Suppression by glutamate of cGMP-activated conductance in retinal bipolar cells. Nature 346:269-271.

Nygaard RW, Frumkes TE (1982). LEDs: convenient, inexpensive sources for visual experimentation. Vision Res 22:435-440.

Roska B, Werblin F (2000) Formation of parallel image representations at rabbit ganglion cells. Invest Ophthalmol Vis Sci 41:S761.

Roska B, Gaal L, Werblin FS (1998) Voltage-dependent uptake is a major determinant of glutamate concentration at the cone synapse: an analytical study. J Neurophysiol 80:1951-1960.

Roska B, Nemeth E, Orzo L, Werblin FS (2000) Three levels of lateral inhibition: a space-time study of the retina of the tiger salamander J Neurosci 20:1941-1951.

Saito T, Kujiraoka T (1982) Physiological and morphological identification of two types of on-center bipolar cells in the carp retina. J Comp Neurol 205:161-170.

Shiells RA, Falk G (1999) A rise in intracellular $\mathrm{Ca}^{2+}$ underlies light adaptation in dogfish retinal "on" bipolar cells. J Physiol (Lond) 514:343-350.

Shiells RA, Falk G, Naghshineh S (1981) Action of glutamate and aspartate analogues on rod horizontal and bipolar cells. Nature 294:592-594.

Slaughter MM, Miller RF (1981) 2-Amino-4-phosphonobutyric acid: a new pharmacological tool for retina research. Science 211:182-185.

Slaughter MM, Miller RF (1985) Characterization of an extended glutamate receptor of the on bipolar neuron in the vertebrate retina. J Neurosci 5:224-233.

Stockton RA, Slaughter MM (1989) B-wave of the electroretinogram. A reflection of ON bipolar cell activity. J Gen Physiol 93:101-122.

Tabata T, Ishida AT (1996) Transient and sustained depolarization of retinal ganglion cells by Ih. J Neurophysiol 75:1932-1943.

Tachibana M, Kaneko A (1988) Retinal bipolar cells receive negative feedback input from GABAergic amacrine cells. Vis Neurosci 1:297-305.

Thoreson WB, Miller RF (1993) Membrane currents evoked by excitatory amino acid agonists in ON bipolar cells of the mudpuppy retina. J Neurophysiol 70:1326-1338.

Thoreson WB, Velte TJ, Miller RF (1995) Actions of phenylglycine derivatives at L-AP4 receptors in retinal ON bipolar cells. Neuropharmacology 34:27-34.

Thoreson WB, Gottesman J, Jane DE, Tse HW, Watkins JC, Miller RF (1997) Two phenylglycine derivatives antagonize responses to L-AP4 in ON bipolar cells of the amphibian retina. Neuropharmacology 36:13-20.

Tian N, Slaughter MM (1994) Pharmacological similarity between the retinal APB receptor and the family of metabotropic glutamate receptors. J Neurophysiol 71:2258-2268.

Toms NJ, Jane DE, Kemp MC, Bedingfield JS, Roberts PJ (1996) The effects of $(R S)$-alpha-cyclopropyl-4-phosphonophenylglycine ((RS)-CPPG), a potent and selective metabotropic glutamate receptor antagonist. $\mathrm{Br} \mathrm{J}$ Pharmacol 119:851-854.

Trussell LO, Zhang S, Raman IM (1993) Desensitization of AMPA receptors upon multiquantal neurotransmitter release. Neuron 10:1185-1196.

von Gersdorff H, Schneggenburger R, Weis S, Neher E (1997) Presynaptic depression at a calyx synapse: the small contribution of metabotropic glutamate receptors. J Neurosci 17:8137-8146.

Werblin FS, Dowling JE (1969) Organization of the retina of the mudpuppy, Necturus maculosus. II. Intracellular recording. J Neurophysiol 32:339-355.

Wu SM (1987) Synaptic connections between neurons in living slices of the larval tiger salamander retina. J Neurosci Methods 20:139-149.

Wu SM, Gao F, Maple BR (2000) Functional architecture of synapses in the inner retina: segregation of visual signals by stratification of bipolar cell axon terminals. J Neurosci 20:4462-4470.

Wunk DF, Werblin FS (1979) Synaptic inputs to the ganglion cells in the tiger salamander retina. J Gen Physiol 73:265-286.

Xu X, Karwoski C (1995) Current source density analysis of the electroretinographic d wave of frog retina. J Neurophysiol 73:2459-2469.

Zhang J, Slaughter MM (1995) Preferential suppression of the ON pathway by $\mathrm{GABA}_{\mathrm{C}}$ receptors in the amphibian retina. $\mathrm{J}$ Neurophysiol 74: $1583-1592$. 